\title{
Review \\ Chimeric Antigen Receptor T-Cell Therapy: The Light of Day for Osteosarcoma
}

\author{
Zili Lin (1), Ziyi Wu and Wei Luo*
}

Citation: Lin, Z.; Wu, Z.; Luo, W. Chimeric Antigen Receptor T-Cell Therapy: The Light of Day for Osteosarcoma. Cancers 2021, 13, 4469. https://doi.org/10.3390/ cancers 13174469

Academic Editors: Antonio Curti, Alessandro Isidori, Giuseppe Lo Russo and Marina Chiara Garassino

Received: 27 July 2021

Accepted: 28 August 2021

Published: 5 September 2021

Publisher's Note: MDPI stays neutral with regard to jurisdictional claims in published maps and institutional affiliations.

Copyright: (c) 2021 by the authors. Licensee MDPI, Basel, Switzerland. This article is an open access article distributed under the terms and conditions of the Creative Commons Attribution (CC BY) license (https:// creativecommons.org/licenses/by/ $4.0 /)$.
Department of Orthopaedics, Xiangya Hospital, Central South University, Changsha 410008, China; woslinzili@163.com (Z.L.); wzy15021@163.com (Z.W.)

* Correspondence: luowei0928@126.com

Simple Summary: As a novel immunotherapy, chimeric antigen receptor (CAR) T-cell therapy has achieved encouraging results in leukemia and lymphoma. Furthermore, CAR-T cells have been explored in the treatment of osteosarcoma (OS). However, there is no strong comprehensive evidence to support their efficacy. Therefore, we reviewed the current evidence on CAR-T cells for OS to demonstrate their feasibility and provide new options for the treatment of OS.

Abstract: Osteosarcoma (OS) is the most common malignant bone tumor, arising mainly in children and adolescents. With the introduction of multiagent chemotherapy, the treatments of OS have remarkably improved, but the prognosis for patients with metastases is still poor, with a five-year survival rate of $20 \%$. In addition, adverse effects brought by traditional treatments, including radical surgery and systemic chemotherapy, may seriously affect the survival quality of patients. Therefore, new treatments for OS await exploitation. As a novel immunotherapy, chimeric antigen receptor (CAR) T-cell therapy has achieved encouraging results in treating cancer in recent years, especially in leukemia and lymphoma. Furthermore, researchers have recently focused on CAR-T therapy in solid tumors, including OS. In this review, we summarize the safety, specificity, and clinical transformation of the targets in treating OS and point out the direction for further research.

Keywords: osteosarcoma; CAR-T therapy; solid tumors; immune checkpoint; targeted therapy

\section{Introduction}

Osteosarcoma (OS) is the most observed malignant primary bone tumor and chiefly affects children and adolescents [1]. With the introduction of multiagent chemotherapy, the long-term overall survival rate for OS varies from 60-70\% [2]. However, the prognosis for patients with metastatic or relapsed OS has remained bleak and stagnant over the past 30 years, with a five-year overall survival rate of $20 \%$ [3-5]. In addition, the adverse effects brought by conventional treatments, including radical surgery and systemic chemotherapy, seriously affect the survival quality of patients. Therefore, new treatments for OS are urgently needed. Over the past few decades, immunotherapy has played an increasingly important role in treating cancer [6], with monoclonal antibodies (MABs) and chimeric antigen receptors (CARs) receiving much attention $[7,8]$.

CARs are engineered receptors composed by an extracellular single-chain variable fragment ( $\mathrm{scFv}$ ) derived from a monoclonal antibody, a transmembrane domain, and an intracellular domain derived from the T-cell receptor $\mathrm{CD} 3-\zeta$ chain. In the lab, technicians activate $\mathrm{T}$ cells and genetically engineer CARs onto their membranes, transforming $\mathrm{T}$ cells into chimeric antigen receptor T (CAR-T) cells (Figure 1). The intracellular domains of CART cells can bind to costimulatory molecules, such as CD28 and 41BB. The CARs without costimulatory molecules are the first-generation CARs, the CARs with one costimulatory molecule are the second-generation CARs, and the CARs with two costimulatory molecules are the third-generation CARs [9]. CARs transfer specific antigens to immune effector cells (typically T cells), providing them with the ability to target tumors [10]. Therefore, CARs 
can enable T cells to produce potent antitumor activity without the limitation of traditional major histocompatibility complexes (MHCs) [11-13]. Compared with traditional therapies, CARs have the following advantages: (1) cells loaded with CARs can target tumor tissues, leading to more precise and less invasive therapy; (2) cells loaded with CARs can still have a strong lethality to metastatic or recurrent tumor cells [14]. Compared with MABs, CARs have the following advantages: (1) MABs can fail to recognize tumor cells when they express too little antigen, while CARs can overcome this dilemma; (2) immune cells loaded with CARs can not only kill tumor cells directly but also secrete cytokines, such as IFN- $\gamma$ and IL-2, exerting powerful antitumor effects; (3) immune cells loaded with CARs can proliferate massively and exert long-lasting anti-tumor effects after infusion [13,15-17]. Taken together, CARs may offer a promising approach for the treatments of cancer.

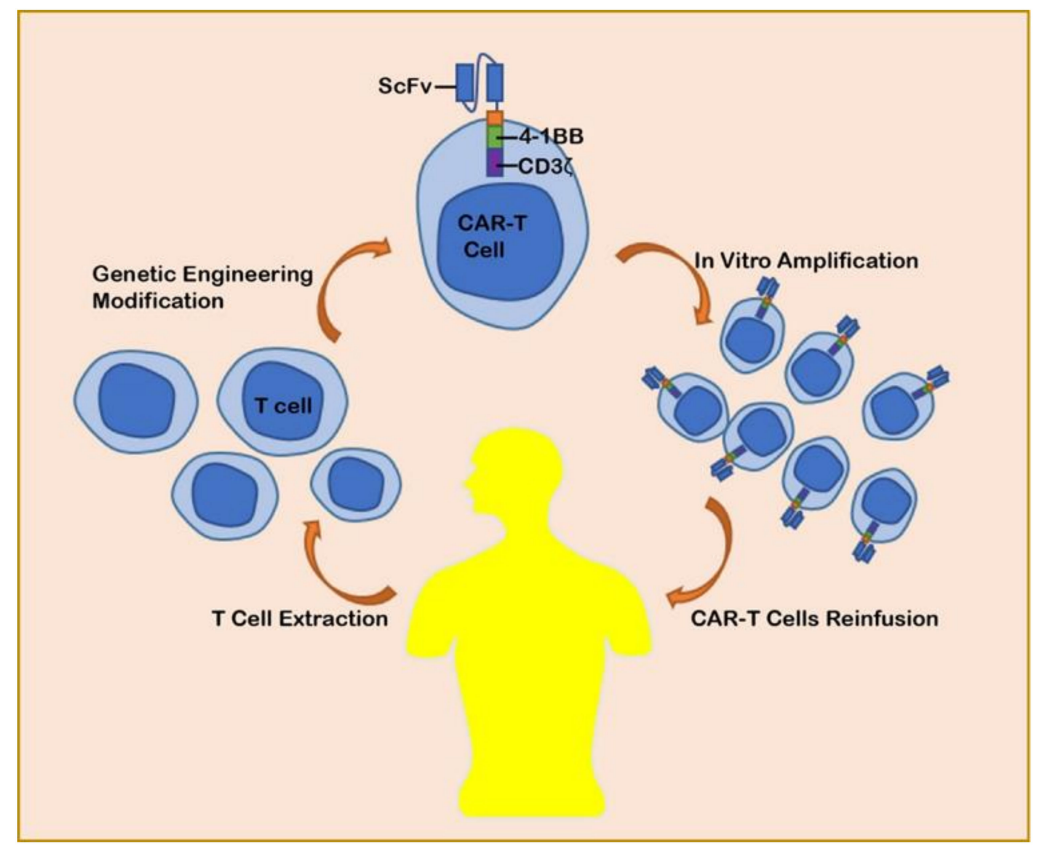

Figure 1. Flowchart of CAR-T cells production.

Over the years, CAR-T cells have gained prominence in treating cancers, especially leukemia and lymphoma [18]. Significant clinical responses and high complete response rates have been observed in CAR-T therapy for B-cell malignancies. Based on these encouraging results, the Food and Drug Administration (FDA) recently approved two CAR-T cells targeting the CD19 protein for the treatment of acute lymphoblastic leukemia and diffuse large B-cell lymphoma [19]. Recently, researchers have also extended CAR-T therapy to solid tumors, including OS [20-22]. Koksal et al. summarized CAR-T-cell therapy for OS several years ago [22]. However, given that new CAR-T therapies for OS have been emerging in recent years, we feel it necessary to provide a more comprehensive review of CAR-T-cell therapy for OS.

\section{Research on CAR-T Cells Targeting OS Antigens}

The key step in the generation of CAR-T cells is finding and targeting the tumor precisely, reducing damage to normal tissue. Currently, the main targets of CAR-T cells in OS treatment are as follows: human epidermal growth factor receptor 2 (HER2), disialoganglioside (GD2), B7-H3 (clusters of differentiation protein 276, CD276), Interleukin-11 receptor a-chain (IL-11Ra), type I insulin-like growth factor receptor (IGF1R), receptor tyrosine kinase-like orphan receptor 1 (ROR1), erythropoietin-producing hepatocellular receptor tyrosine kinase class A2 (EphA2), natural killer group 2D (NKG2D), activated leukocyte cell adhesion molecule (ALCAM, CD166), and chondroitin sulfate proteoglycan 4 (CSPG4) (Figure 2, Table 1) [23-30]. 


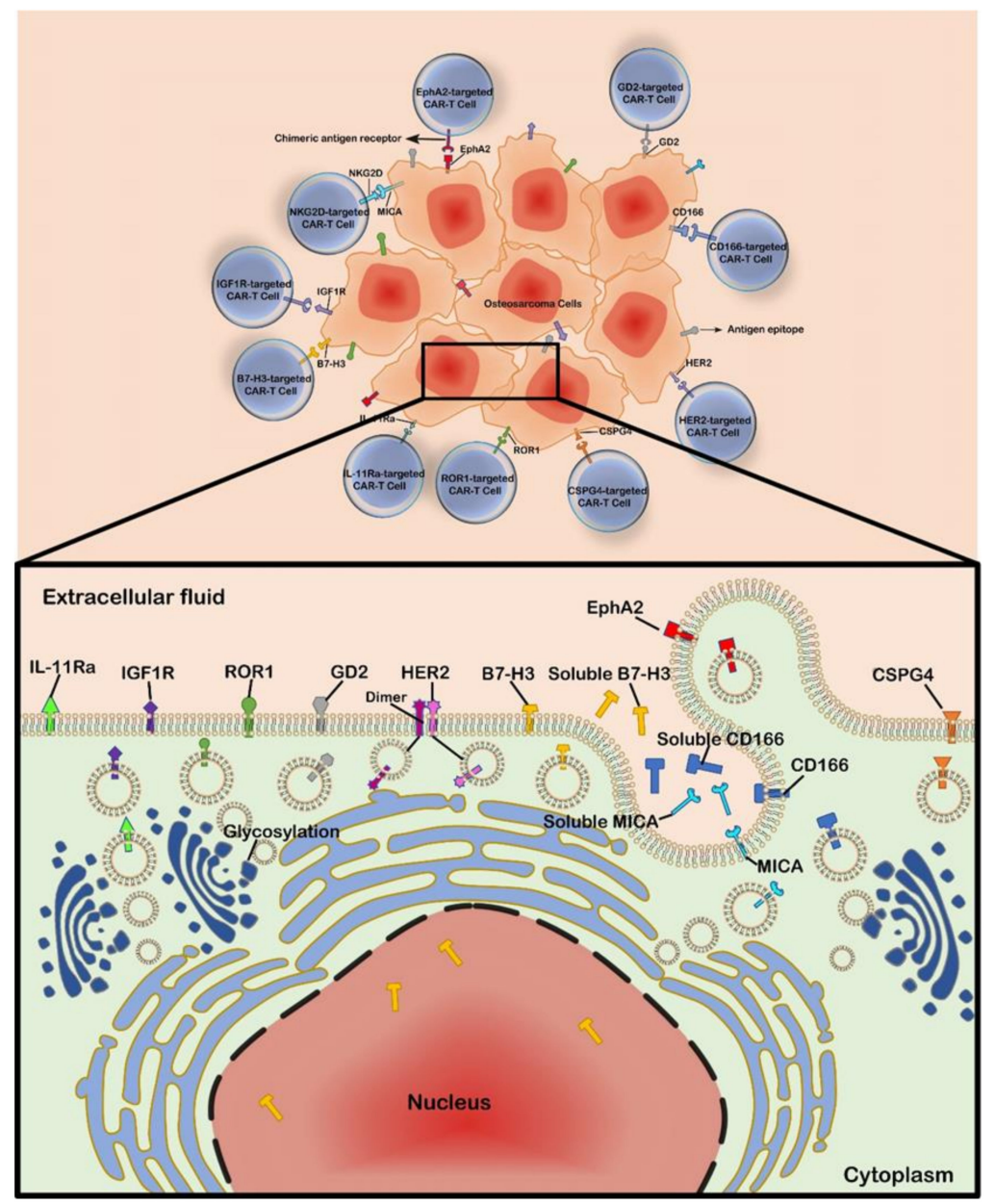

Figure 2. The main targets of CAR-T cells for OS treatment.

Table 1. Targets of CAR-T cells in OS.

\begin{tabular}{|c|c|c|c|c|}
\hline & Characteristics & Expression in Normal Tissue & $\begin{array}{l}\text { Kills OS Cells and/ } \\
\text { or Metastases }\end{array}$ & References \\
\hline HER2 & A tyrosine-protein kinase & Low expression in normal tissue & Kills OS cells and metastases & {$[15,23,31-34]$} \\
\hline GD2 & $\begin{array}{l}\text { An N-acetyl neuraminic acid-containing } \\
\text { glycolipid antigen }\end{array}$ & Low expression in normal tissue & Kills OS cells & {$[23,35-38]$} \\
\hline B7-H3 & $\begin{array}{l}\text { A member of the B7 family } \\
\text { of immunoregulatory proteins }\end{array}$ & Low expression in normal tissue & Kills OS cells and metastases & {$[29,39,40]$} \\
\hline IL-11Ra & $\begin{array}{l}\text { A member of the } \\
\text { PI3K, MAPK and JAK-STAT activating } \\
\text { family of cytokines/receptors }\end{array}$ & Low expression in normal tissue & Kills OS cells and metastases & {$[24,41]$} \\
\hline IGF1R & A transmembrane glycoprotein & $\begin{array}{l}\text { Widely distributed in normal tissues, such } \\
\text { as myocardium, brain, bone, and cartilage }\end{array}$ & Kills OS cells & {$[25,42,43]$} \\
\hline ROR1 & A type I transmembrane protein & $\begin{array}{l}\text { Expression in normal tissue, particularly } \\
\text { high in the gastric antrum and body }\end{array}$ & Kills OS cells & {$[25,44,45]$} \\
\hline NKG2D & $\begin{array}{l}\text { A powerful activating receptor expressed } \\
\text { by natural killer (NK) cells and T cells }\end{array}$ & Expressed by NK cells and T cells & Kills OS cells & {$[46,47]$} \\
\hline EphA2 & A tyrosine kinase receptor & Mainly confined to some epithelial cells & Kills OS cells and metastases & {$[30,48-50]$} \\
\hline CD166 & $\begin{array}{l}\text { A type I membrane protein, a member of } \\
\text { the immunoglobulin gene superfamily, } \\
\text { and a ligand for the lymphocyte } \\
\text { antigen CD6 }\end{array}$ & $\begin{array}{l}\text { Broadly expressed in various tissues and } \\
\text { cells, including neuronal, immune, and } \\
\text { epithelial cells, as well as stem cells of } \\
\text { hematopoietic and mesenchymal origin }\end{array}$ & Kills OS cells & {$[27,51,52]$} \\
\hline CSPG4 & A transmembrane proteoglycan & Low expression in normal tissue & Kills OS cells & [53-55] \\
\hline
\end{tabular}




\subsection{Human Epidermal Growth Factor Receptor 2 (HER2)}

The human epidermal growth factor receptor (HER) family consists of four members, HER1-4, which comprise essentially a class of tyrosine-protein kinases that functions as both homodimer and heterodimer. Their ligands include epidermal growth factor (EGF) and transforming growth factor- $\alpha$ (TGF- $\alpha$ ). After binding with ligands, they activate the downstream signaling pathway and produce a series of physiological or pathological reactions. Unlike other members, HER2 does not bind to any ligand and performs its function by forming a heterodimer with other members [31]. The formation of a heterodimer is typically due to HER2 overexpression, leading to autophosphorylation of tyrosine residues in the cytoplasmic domain of the heterodimer and initiating various signaling pathways contributing to cell proliferation and tumorigenesis [56]. HER2-targeted therapy for cancer has been widely studied and has yielded encouraging results in the treatment of breast cancer [32]. In addition, HER2 overexpression has been reported in other solid tumors, such as pancreatic adenocarcinomas, colorectal carcinomas, and gastric cancer [33]. In addition, relevant studies have shown that HER2 is also expressed in OS [57-59]; therefore, HER2-targeted therapy in treating OS is worthy of study. Ahmed et al. showed that HER2-targeted CAR-T cells secrete immunostimulatory cytokines and proliferate after exposure to HER2-positive OS cells. The transfer of HER2-targeted CAR-T cells into mouse models with xenografted OS resulted in tumor regression and remission in mouse models with OS lung metastasis [15]. Experiments conducted by Rainusso et al. showed that HER2-targeted CAR-T cells significantly reduced sarcosphere formation capacity and bone tumor growth in immunodeficient mice after orthotopic transplantation. Additionally, they found this in vivo, giving HER2-targeted CAR-T cells markedly reduced drug-resistant tumor-initiating cells in bulky OS [34]. Similarly, HER2-targeted CAR-T cells displayed significant antitumor activity in the study conducted by Park and colleagues [23]. In a phase I/II clinical study, Ahmed et al. evaluated the feasibility and safety of escalating doses of HER2-targeted CAR-T cells in patients with recurrent or refractory sarcomas, including OS. They found that infusion of $1 \times 10^{8} / \mathrm{m}^{2}$ of HER2-targeted CAR-T cells was well tolerated, with stable disease lasting from 12 weeks to 14 months in 4 of 17 evaluable patients. After removal of residual metastases, three patients remained in remission at 6 , 12, and 16 months. Their experiments showed that a safe dose of HER2-targeted CAR-T cells can be established for cancer patients. In addition, HER2-targeted CAR-T cells can be transported to the tumor site and maintained at low levels in a dose-dependent manner for more than 6 weeks [60]. These experiments have confirmed that HER2-targeted CAR-T cells can not only kill tumor-initiating cells in OS that lead to OS recurrence but can also eliminate OS metastatic lesions, which are responsible for the deaths of OS patients. Thus, HER2-targeted CAR-T cells are a potentially worthy treatment. However, although Ahmed et al. demonstrated the safety of HER2-targeted CAR-T cells, Morgan RA's case report is of concern. In the Morgan RA case report, a patient died after a cytokine storm following treatment with HER2-targeted CAR-T cells [61]. To address this problem, Mata et al. created a canine HER2-targeted CAR-T cell. They found that although the cytolytic activity of canine HER2-targeted CAR-T cells was similar to their previous studies using human HER2-targeted CAR-T cells [15], cytokine production was lower [62]. This large animal model may be valuable in evaluating the development of CAR-T cells for future human clinical trials. Therefore, to transform HER2-targeted CAR-T cells into clinical usage, strategies to address their adverse effects should be investigated. In view of the cytokine storm, we can introduce a coexpressed suicide gene or inhibitive receptors into CAR-T cells to properly limit their functions.

\subsection{Disialoganglioside (GD2)}

Disialoganglioside (GD2), an N-acetyl neuraminic acid-containing glycolipid antigen, is composed of five monosaccharides anchored to the lipid bilayer of the plasma membrane through a ceramide lipid [35]. GD2 expression is low in normal tissues [36] but high in solid tumors in children and adults, including neuroblastomas, Ewing's sarcoma, and OS [63]. 
GD2 is often used in treating neuroblastomas and has achieved encouraging results [64]. The study by Roth et al. showed that OS can express more GD2 than neuroblastomas [65]. Therefore, targeting GD2 for OS seems reasonable. Long et al. observed $100 \%$ expression of GD2 in OS and that third-generation GD2-targeted CAR-T cells mediated efficient and comparable lysis of $\mathrm{GD}^{+}{ }^{+}$sarcoma cell lines in vitro [37]. In another experiment, Chulanetra et al. demonstrated that GD2-targeted CAR-T cells were very effective in inducing OS tumor cell death. In further experiments, they showed that suboptimal treatment with doxorubicin can effectively kill OS tumor cells in conjunction with CAR-T cells [38]. Park and Cheung also demonstrated that GD2-targeted CAR-T-cell therapy enabled effective T cells to infiltrate tumors and exert potent antitumor activity in OS. Moreover, there was more T-cell infiltration in tumors when combined with anti-PD-L1 (programmed death ligand 1), especially when anti-PD-L1 was applied after GD2-targeted therapy [23]. However, although GD2-targeted CAR-T-cell therapy is a promising approach for treating OS, there are still many problems that still need to be solved. Long et al. found that GD2-targeted CAR-T cells had no antitumor effect against GD2 ${ }^{+}$sarcoma in xenograft models. They further found that xenografts from pediatric sarcoma induced myeloid-derived suppressor cells (MDSCs) to inhibit human CAR-T-cell responses in vitro. However, this inhibition disappeared with the addition of all-trans retinoic acid, suggesting that all-trans retinoic acid improved the antitumor ability of GD2-targeted CAR-T cells [37]. In addition, Chulanetra et al. discovered that after interacting with GD2-targeted CAR-T cells, OS cells can upregulate PD-L1 expression. Moreover, this specific interaction induced CAR-T cells to overexpress the exhaustion marker PD-1, leading to CAR-T-cell apoptosis [38], supporting the experimental conclusions of Park and Cheung [23]. Therefore, improving the efficiency of GD2-targeted CAR-T cells is essential to its transformation into the clinic. One strategy is to combine GD2-targeted CAR-T cells with immune checkpoint blockade. Related studies have shown that combining GD2-targeted CAR-T cells and anti-PD-L1 can improve the antitumor effect of GD2-targeted CAR-T cells [23]. Furthermore, the ability of other immune checkpoint blockades to coordinate with GD2-targeted CAR-T cells is also worthy of exploring. Another strategy is to construct bispecific CAR-T cells. Various studies have shown that MDSCs can inhibit CAR-T cell responses and express the NKG2D ligand [66]. Thus, constructing GD2-targeted CAR-T cells loaded with NKG2D may be a viable method to strengthen the function of GD2-targeted CAR-T cells. In addition, Kailayangiri et al. reported that inhibition of enhancer of zeste homolog $2(\mathrm{EZH} 2)$ can upregulate tumor antigen GD2 synthase expression to upregulate the expression of GD2 [67]. Therefore, upregulating the tumor antigen expressed in OS by epigenetics is a viable approach.

\subsection{B7-H3 (CD276, Clusters of Differentiation Protein 276)}

B7-H3 is an immune checkpoint in the B7 family of molecules that interacts with checkpoint markers, such as CTLA4 (cytotoxic T lymphocyte-associated antigen 4) and PD-1. Human B7-H3 protein exists in transmembrane or soluble form. Transmembrane B7-H3 is present not only on the surface of tumor cells but also in cytoplasmic vesicles and the nucleus [39]. Related studies have suggested that B7-H3 plays an essential role in the proliferation, invasion, and migration of malignant tumor cells [68-71]; therefore, B7-H3 can be used as a target for tumor immunotherapy. Indeed, B7-H3 has been used in many cancers, including acute myeloid leukemia, non-small-cell lung cancer, and neuroblastoma [72-74]. Moreover, B7-H3 is expressed in OS, and 8H9, a MAB targeting B7-H3, has also been used against OS [75-78]. Therefore, research on treating OS with B7-H3-targeted CAR-T is also being explored. Majzner et al. showed that systemic administration of B7-H3-targeted CAR-T cells mediated the regression and eradication of OS xenografts. In addition, a model of the highly metastatic OS with a 100\% lethality survived almost completely after treatment with B7-H3-targeted CAR-T cells [29]. Murty et al. showed that B7H3-targeted CAR-T cells had an antitumor effect on naturally expressing B7H3 OS cells in an in vitro co-culture assay. Furthermore, an advanced orthotopic model of human OS treated with B7-H3-targeted CAR-T cells showed significantly reduced tumor 
volume with prolonged overall survival [40]. Therefore, laboratory evidence has suggested that B7-H3-targeted CAR-T cells have the potential as a therapeutic approach for OS and exploring methods to improve this effect can speed the clinical transformation. Related studies have reported that B7-H3 may participate in the JAK/STAT and PI3K/Akt/mTOR pathways and that the inhibition of B7-H3 increases the response of tumor cells to inhibitors of these pathways [79,80]. Consequently, combining B7-H3-targeted CAR-T cells with chemotherapy may serve as a synergistic treatment approach.

\subsection{Interleukin-11 Receptor a-Chain (IL-11Ra)}

IL-11, a member of the family of pleiotropic cytokines, is both a pro- and an antiinflammatory cytokine $[81,82]$. The specific binding of IL-11 to IL-11Ra mediates the assembly of a multi-subunit receptor complex. Then, the receptor complex can initiate intracellular signaling through association with the transmembrane signal transducer glycoprotein gp-130, leading to a series of physiological and pathological responses [82,83]. IL-11Ra is involved in the development and aggressive activity of various cancers $[41,84]$. In recent years, the role of IL-11Ra in OS has also attracted attention [85]. Lewis et al. found that IL-11R $\alpha$ was significantly expressed in primary OS and pulmonary metastatic OS in an orthotopic mouse model but absent from the control normal tibia and lung. Moreover, IL-11R $\alpha$ expression in large samples of human primary and metastatic OS was significantly consistent with the observed results in an orthotopic mouse model [86]. Similarly, Liu et al. reported that OS can highly express IL-11R $\alpha$ and that near-infrared labeled IL-11R $\alpha$ imaging agents can detect $O S$ in mouse tumor xenografts [87]. In one experiment, G. Huang and colleagues demonstrated that OS cell lines and OS lung metastases express IL-11Ra. Furthermore, they engineered IL-11Ra-targeted CAR-T cells, demonstrating that these cells kill OS cells and accumulated in lung metastases rather than in surrounding normal lung tissue. However, because IL-11Ra is not $100 \%$ expressed on each osteosarcoma cell, it needs to be combined with other therapies to improve its efficacy [24]. In addition, constructing bispecific CAR-T cells is also an alternative method.

\subsection{Type I Insulin-Like Growth Factor Receptor (IGF1R)}

IGF1R is a transmembrane glycoprotein that stimulates the growth of tumor cells by autocrine signaling, induces metastasis, and inhibits apoptosis $[42,43,88]$. IGF1R overexpression has been found in many human cancers, including OS, and the application of IGF1R in treating OS has also been explored [88-90]. In one study, researchers found that OS cells, including those resistant to various conventional anticancer drugs, are sensitive to IGF1R inhibitors. Blocking IGF1R could inhibit proliferation and induce apoptosis of OS cell lines [91]. A recent study evaluated IGF1R-targeted CAR-T cells in sarcomas and found that IGF1R-targeted CAR-T cells remarkedly reduced tumor growth in pre-established, localized, and systemically disseminated OS mouse models. In addition, the adoptive transfer of IGF1R-targeted CAR-T cells also displayed a prolonged survival benefit in a localized sarcoma model [25]. IGF1R is also expressed in normal tissues [43]; therefore, the potential toxicity of IGF1R-targeted therapy should not be ignored. In addressing this problem, we can adjust the affinity between CAR-T cells and the tumor-associated antigens to properly limit the function of CAR-T cells to reduce off-target toxicity.

\subsection{Receptor Tyrosine Kinase-Like Orphan Receptor 1 (ROR1)}

ROR1 is a type I transmembrane protein that is physiologically expressed during early embryogenesis and plays a key role in organogenesis. It is rarely expressed in tissues after birth but is expressed in various cancers, especially those with low differentiation [44]. In recent years, ROR1 has attracted attention as an immune target. Cirmtuzumab, a humanized MAB that blocks ROR1 signaling, was effective and safe in patients with advanced, relapsed, or refractory chronic lymphoblastic leukemia in a phase I trial [44]. One study revealed that ROR1 MAB markedly blocked the migration of OS cells, suggesting ROR1 may be a novel therapeutic target to delay OS metastasis [92]. Furthermore, X. Huang 
et al. demonstrated that ROR1 is highly expressed in sarcoma cell lines, including Ewing's sarcoma, OS, rhabdomyosarcoma, and fibrosarcoma. In addition, their studies indicated that ROR1-targeted CAR-T cells showed specific cytotoxicity and released mainly IFN- $\gamma$, TNF- $\alpha$, and IL-13 cytokines against sarcomas in vitro. They further found that ROR1targeted CAR-T cells remarkedly suppressed sarcoma growth in pre-established localized and disseminated sarcoma xenograft models associated with prolonged survival [25]. Although the above experiments proved that ROR1-targeted CAR-T cells may be a promising target for treating OS, the safety of ROR1-targeted CAR-T cells cannot be ignored. Recent studies have shown that ROR1 expression is not specific to tumor tissue. ROR1 has been observed in other normal tissues in humans, high in the gastric antrum and body, although experiments in the macaque model have shown no significant adverse effects [45]. Additionally, the logic-gated ROR1 CAR designed by Srivastava et al. can protect healthy tissues and target tumor cells, promising to address the off-target toxicity [93].

\subsection{Natural Killer Group 2D (NKG2D)}

NKG2D is a powerful activating receptor expressed by natural killer (NK) cells and $\mathrm{T}$ cells that are involved in immune responses during infection, cancer, and autoimmunity [46]. In recent years, the role of NKG2D and its ligands in cancer has attracted increasing attention [94-96]. MHC class I chain-related molecule A (MICA) is a major ligand for activating immune receptor NKG2D [46,97]. MICA is commonly expressed at mRNA and protein levels in OS. Furthermore, MICA expression was upregulated in OS compared with benign tumors and normal bone tissue. Restoration of NKG2D receptor expression on immune effector cells may contribute to therapeutic strategies for human OS $[97,98]$. Chang et al. significantly increased the surface expression of NKG2D in NK cells by retroviral transduction of NKG2D-DAP10-CD3z. They found that in immunodeficient mice transplanted with OS cells, NK cells expressing the NKG2D-DAP10-CD3z receptor had great antitumor activity and produced significant tumor reduction, while the simulated transduction-activated NK cells were ineffective [99]. Fernandez et al. extended NKG2D to T cells by creating NKG2D CAR-redirected memory T cells that strengthened cytotoxicity against OS cells in vitro, compared with untransduced T cells. Moreover, in vivo, tumor growth was restricted, and survival was prolonged in mice that received NKG2D CAR-redirected memory T cells. In addition, NKG2D CAR-redirected memory T cells showed no lytic activity against healthy cells and no chromosomal aberrations due to lentiviral transduction [47]. Based on these studies, intervening NKG2D receptors on immune cells may be a strategy for treating OS. However, Van Seggelen et al. recently described lethal toxicity in mice treated with murine NKG2D-redirected CAR-T cells [26], raising safety concerns. Research conducted by Fernandez et al. showed that adult health tissues are not sensitive to NKG2D-redirected CAR-T-cell cytotoxicity [47]. In addition, an ongoing phase I dose-escalation study to test the safety of NKG2D-redirected CAR-T cells in patients with myeloid malignancies did not show any significant adverse effects [100]. Although safety problems have been reported in animal experiments, adverse reactions in human beings have not been reported. However, the safety of NKG2D-redirected CAR-T cells cannot be ignored. We can adjust the affinity between CAR-T cells and the antigen epitopes to suitably limit the function of CAR-T cells to reduce off-target toxicity.

\subsection{Erythropoietin-Producing Hepatocellular Receptor Tyrosine Kinase Class A2 (EphA2)}

EphA2 is a tyrosine kinase receptor involved in ephrin signaling during embryonic development, and its post-developmental expression is mainly confined to some epithelial cells [48-50]. EphA2 overexpression has been widely reported in various cancer [101,102] and plays an important role in OS [103]. There are also many drugs targeting EphA2 for treating OS, and they have achieved some efficacy [104-106]. Related studies also have suggested the EphA2 receptor may be an attractive candidate receptor for the targeted delivery of therapeutics to OS [107]. Hsu and colleagues showed that EphA2-targeted CAR-T cells effectively killed EphA2-expressing OS tumor cells in pre-established, targeted 
xenografts in immunodeficient mice and were associated with prolonged survival. In addition, EphA2-targeted CAR-T cells remarkedly reduced or eliminated tumor burden in a mouse model of disseminated OS metastasis. However, EphA2 has its limits, including an increase in EphA2-negative tumor cells after treatment with EphA2-targeted CAR-T cells, which may lead to tumor immune escape [30]. Therefore, EphA2 should be an ideal target for treating OS, but immune evasion after treatment must be addressed. One approach is to construct bispecific CAR-T cells to target EphA2-negative tumor cells. Another approach is to combine EphA2-targeted CAR-T cells with immune checkpoint blockade or chemotherapy.

\subsection{Activated Leukocyte Cell Adhesion Molecule (ALCAM, CD166)}

CD166 (ALCAM), a type I membrane protein, is a member of the immunoglobulin gene superfamily and a ligand for the lymphocyte antigen CD6 [51]. CD166 has three different subtypes, namely membrane CD166, cytoplasmic CD166, and soluble CD166 [108]. Many studies have shown that CD166 is associated with the occurrence and development of various malignancies, including intestinal carcinoma, glioblastoma, and prostate cancer [52,109-111]. Previous studies also showed that OS cells can express CD166 [112,113], and targeting OS through CD166 has also achieved a certain effectiveness [114]. Wang et al. showed that OS cell lines express CD166 in varying levels. They further found that CD166-targeted CAR-T cells incorporated with 4-1BB showed cytotoxicity to OS in vitro and in vivo; the cytotoxicity of which was closely related to the expression of CD166 [27]. However, CD166-targeted CAR-T-cell therapy also has some limits. CD166 is present not only in tumors but also in some normal tissues, such as epithelial cells, fibroblasts, and neurons [115-117]. Thus, although Wang and his team showed that CD166-targeted CAR-T cells were safe, we still cannot ignore this issue. The aforementioned methods, including adjusting the affinity between CAR-T cells and antigen epitopes or constructing logic-gated CAR, may serve as a solution to this issue.

\subsection{Chondroitin Sulfate Proteoglycan 4 (CSPG4)}

CSPG4, a transmembrane proteoglycan, is lowly expressed in normal tissues but highly expressed in several solid tumors and plays a central tumorigenic role [53-55]. In recent years, CSPG4 has become a CAR-target antigen for many different cancer entities [28]. Relevant experiments have shown that both human and canine OS cells highly express CSPG4, and high CSPG4 expression is associated with short survival. CSPG4 immune-targeted therapy for OS can significantly inhibit the proliferation, migration, and osteogenesis of CSPG4-positive OS cells [53,118]. Beard et al. found that CSPG4targeted CAR-T cells showed cytokine secretion and cytolytic function after co-culture with OS cells [53]. However, evidence for CSPG4-targeted CAR-T cells in treating OS is far from enough; thus, we are not able to accurately evaluate their efficacy. Therefore, more experiments should be conducted.

\section{Discussion}

OS is a primary malignant bone tumor with a global incidence of 3.4 per 1 million people each year $[119,120]$. Despite multiple changes in adjuvant chemotherapy regimens for patients with OS, the overall survival rate for patients with OS has staggered at $60-70 \%$ over the past decades [2]. The prognosis for patients with metastatic or relapsed OS remains poor, with a five-year overall survival rate of $20 \%$ [3-5]. In addition, the poor targeting of traditional treatment often brings certain adverse effects [121], and the tumor cells develop resistance to chemotherapeutic drugs [122,123]. Therefore, new and effective treatments await exploitation.

CAR-T-cell therapy is a promising immunotherapy approach with encouraging results in treating leukemia and lymphoma [18]. Because of their high targeting and powerful antitumor activity, CAR-T cells are widely used in research and the treatment of various cancers. Recently, researchers have also extended CAR-T therapy to solid tumors, including 
OS [20-22]. Furthermore, related studies have reported that adoptively transferred effector cells derived from naive $\mathrm{T}$ cells mediate superior antitumor effects, and youth carry more naive cells $[124,125]$. Therefore, CAR-T cells may exert more positive effects in treating OS mainly in youth. Indeed, CAR-T-cell therapy for OS has been explored with certain encouraging progress. Currently, the main targets of CAR-T cells for OS treatment are as follows: HER2, GD2, B7-H3, IL-11Ra, IGF1R, ROR1, NKG2D, EphA2, CD166, and CSPG4. In most of these studies, the researchers found that $T$ cells loaded with the various CARs presented antitumor activity in vitro and in vivo preclinical models, partially associated with extended survival. Therefore, CAR-T cells may be a new therapeutic approach to treat OS. In addition, among all the targets, HER2, IL-11Ra, B7-H3, and EphA2 deserve further study because their CAR-T cells can act on metastases, which are the main causes of death in OS patients $[15,29,30,86]$.

Although CAR-T-cell therapy is a promising approach for OS, some limits still await solutions. The problems include the following:

1. Some targets are not tumor specific; for example, CD166 is present not only in tumors but also in some normal tissues, such as epithelial cells, fibroblasts, and neurons [115-117].

2. Each target is not 100\% expressed in tumor cells, and there has been antigen loss or modulation after CAR-T cell therapy $[126,127]$. Hsu and colleagues reported an increase in EphA2-negative tumor cells following experimental EphA2 CAR treatment of OS [30].

3. Tumor cells may upregulate some surface receptors to induce apoptosis of CAR-T cells; Chulanetra et al. found that OS cells induced CAR-T cell apoptosis by upregulation of PD-L1 [38].

4. Although CAR-T-cell therapy has shown encouraging results in treating leukemia and lymphoma, it is not representative of all cancer therapy; in treating most solid tumors, there are still insurmountable obstacles, including tumor trafficking and tumor microenvironment $[67,128]$.

5. Common adverse effects of CAR-T-cell therapy, such as cytokine storms, are also present in CAR-T-cell therapy for OS; in the Morgan RA case report, a patient died after a cytokine storm following treatment with HER2-targeted CAR-T cells [61].

To address these problems, we can adopt the following solutions:

1. First, we can find more precise targets for tumors. Second, if a target is highly expressed in the tumor tissue and lowly expressed in the normal tissue, we can adjust the therapeutic threshold so it only acts on the tumor tissue, achieving "dose-targeting". Third, adjusting the affinity between CAR-T cells and the tumor-associated antigen can protect the healthy tissue $[129,130]$. Last, a logic-gated CAR is a viable method.

2. The problems of antigen low expression or loss and apoptosis of CAR-T cells can be solved by the following methods:

a. Constructing immune cells expressing multiple CARs or combining multiple CAR-T cells [131].

b. Creating combinations of CAR-T cells with conventional chemotherapeutic agents or MABs.

c. Continuing to improve $\mathrm{T}$ cells, such as entering more costimulatory domains to enhance the killing ability of T cells [132] (Figure 3).

3. To treat solid tumors, the following strategies can be adopted:

a. Some chemokine receptors can recognize the upregulating chemokines in TME; we thus can construct CAR-T cells loaded with these chemokine receptors to increase the infiltration of CAR-T cells. In addition, we can also design CAR-T cells that disintegrate the extracellular matrix proteins forming the physical barrier to TME [133-135].

b. We can construct CAR-T cells that target not only tumor antigens but also immunosuppressive cytokines or immunosuppressive cells, such as MDSCs in TME, to resist tumor immunosuppressive effects on T cells $[37,136]$. 
c. We can strengthen CAR signaling through the proper modulation of CD3 immunoreceptor tyrosine-based activation motifs, which has been reported to reduce T-cell exhaustion [137].

4. We can limit the over-potent function of $\mathrm{T}$ cells by introducing coexpressing suicide genes or inhibitive receptors to avoid cytokine storms [138]. However, further rigorous preclinical and clinical trials of CAR-T cells are necessary to rule out adverse effects.

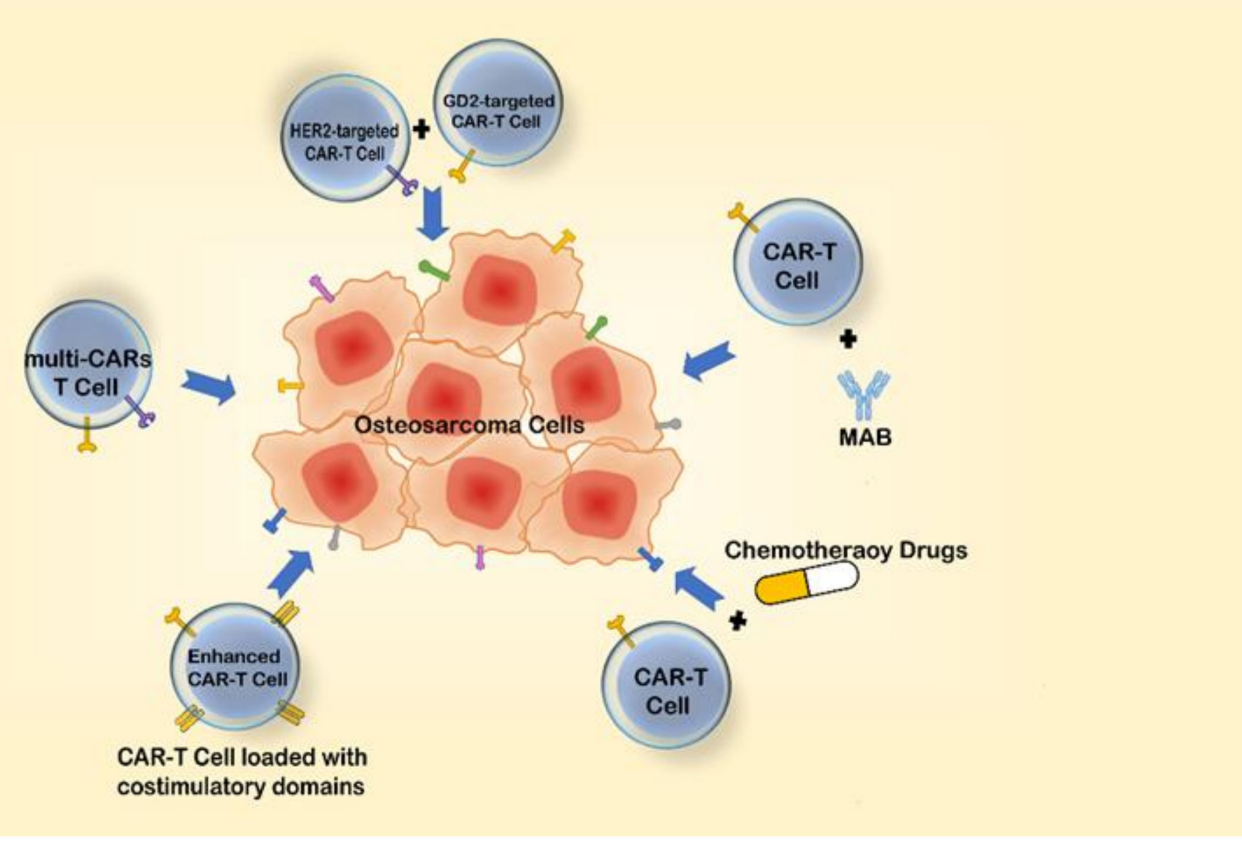

Figure 3. Solutions to enhance the efficacy of CAR-T cell therapy.

Lastly, there are some novel attempts in the treatment of cancers, such as fusion genes. Chromosomal translocations have been associated with the occurrence of certain cancers. Translocation-derived fusion genes can encode some chimeric RNA, commonly transcriptional regulators, generating structurally novel oncogenic fusion proteins [139]. EWS-FLI1 chimeric transcription factor has been widely reported to be involved in the occurrence of Ewing's sarcoma [140-142]. Similarly, this phenomenon has also been identified in OS [143]. The Rab22a-NeoF1 fusion gene has been shown to be expressed in OS and to promote metastasis of OS [144-147]. In addition, EWSR1-CREB3L1 has been identified as a novel fusion transcript in small-cell OS [148], and the FN1-FGFR1 fusion gene may be a target in chondroblastoma-like OS [149]. Therefore, targeting these fusion genes may be a promising strategy. Furthermore, if epitope-targeted CAR-T cells can be effectively combined with fusion gene-targeted therapy, further efficacy may be achieved.

\section{Conclusions}

CAR-T cell therapy for OS is promising, but its practicality and safety require further research.

Author Contributions: W.L. selected the topic and revised the manuscript; Z.L. searched the literature, wrote the manuscript, and figures; and Z.W. searched the literature. All authors have read and agreed to the published version of the manuscript.

Funding: This work was funded by Special funds for the construction of innovative provinces in Hunan Province (2020RC3058).

Institutional Review Board Statement: Not applicable. 
Informed Consent Statement: Not applicable.

Acknowledgments: The authors thank Xiangya Hospital for their support of this writing.

Conflicts of Interest: The authors declare that there was not any conflict of interest in the research.

\section{References}

1. Goorin, A.; Abelson, H.; Frei, E. Osteosarcoma: Fifteen years later. N. Engl. J. Med. 1985, 313, 1637-1643. [CrossRef]

2. Roberts, R.D.; Wedekind, M.F.; Setty, B.A. Chemotherapy regimens for patients with newly diagnosed malignant bone tumors. In Malignant Pediatric Bone Tumors_-Treatment E Management; Springer: Berlin/Heidelberg, Germany, 2015.

3. Aljubran, A.H.; Griffin, A.; Pintilie, M.; Blackstein, M. Osteosarcoma in adolescents and adults: Survival analysis with and without lung metastases. Ann. Oncol. 2009, 20, 1136-1141. [CrossRef]

4. Link, M.P.; Goorin, A.M.; Miser, A.W.; Green, A.A.; Pratt, C.B.; Belasco, J.B.; Pritchard, J.; Malpas, J.S.; Baker, A.R.; Kirkpatrick, J.A.; et al. The effect of adjuvant chemotherapy on relapse-free survival in patients with osteosarcoma of the extremity. $N$. Engl. J. Med. 1986, 314, 1600-1606. [CrossRef] [PubMed]

5. Meyers, P.A.; Healey, J.H.; Chou, A.J.; Wexler, L.H.; Merola, P.R.; Morris, C.D.; Laquaglia, M.P.; Kellick, M.G.; Abramson, S.J.; Gorlick, R. Addition of pamidronate to chemotherapy for the treatment of osteosarcoma. Cancer 2011, 117, 1736-1744. [CrossRef] [PubMed]

6. Hiam-Galvez, K.; Allen, B.; Spitzer, M. Systemic immunity in cancer. Nat. Rev. Cancer 2021, 345-359. [CrossRef]

7. Weiner, L.; Dhodapkar, M.; Ferrone, S. Monoclonal antibodies for cancer immunotherapy. Lancet 2009, 373, 1033-1040. [CrossRef]

8. Wagner, D.; Fritsche, E.; Pulsipher, M.; Ahmed, N.; Hamieh, M.; Hegde, M.; Ruella, M.; Savoldo, B.; Shah, N.; Turtle, C.; et al. Immunogenicity of CAR T cells in cancer therapy. Nat. Rev. Clin. Oncol. 2021, 18, 379-393. [CrossRef]

9. June, C.; Sadelain, M. Chimeric antigen receptor therapy. N. Engl. J. Med. 2018, 379, 64-73. [CrossRef]

10. Sadelain, M.; Brentjens, R.; Rivière, I. The promise and potential pitfalls of chimeric antigen receptors. Curr. Opin. Immunol. 2009, 21, 215-223. [CrossRef]

11. Pule, M.; Finney, H.; Lawson, A. Artificial T-cell receptors. Cytotherapy 2003, 5, 211-226. [CrossRef] [PubMed]

12. Pulè, M.A.; Straathof, K.C.; Dotti, G.; Heslop, H.E.; Rooney, C.M.; Brenner, M.K. A chimeric T cell antigen receptor that augments cytokine release and supports clonal expansion of primary human T cells. Mol. Ther. 2005, 12, 933-941. [CrossRef] [PubMed]

13. Feins, S.; Kong, W.; Williams, E.F.; Milone, M.C.; Fraietta, J.A. An introduction to chimeric antigen receptor (CAR) T-cell immunotherapy for human cancer. Am. J. Hematol. 2019, 94, S3-S9. [CrossRef] [PubMed]

14. Almåsbak, H.; Aarvak, T.; Vemuri, M.C. CAR T cell therapy: A game changer in cancer treatment. J. Immunol. Res. 2016, 2016, 5474602. [CrossRef] [PubMed]

15. Ahmed, N.; Salsman, V.S.; Yvon, E.; Louis, C.U.; Perlaky, L.; Wels, W.S.; Dishop, M.K.; Kleinerman, E.E.; Pule, M.; Rooney, C.M.; et al. Immunotherapy for osteosarcoma: Genetic modification of T cells overcomes low levels of tumor antigen expression. Mol. Ther. 2009, 17, 1779-1787. [CrossRef]

16. Sykulev, Y.; Joo, M.; Vturina, I.; Tsomides, T.J.; Eisen, H.N. Evidence that a single peptide-MHC complex on a target cell can elicit a cytolytic T cell response. Immunity 1996, 4, 565-571. [CrossRef]

17. Anders, K.; Blankenstein, T. Molecular pathways: Comparing the effects of drugs and T cells to effectively target oncogenes. Clin. Cancer Res. 2013, 19, 320-326. [CrossRef]

18. June, C.H.; O'Connor, R.S.; Kawalekar, O.U.; Ghassemi, S.; Milone, M.C. CAR T cell immunotherapy for human cancer. Science 2018, 359, 1361-1365. [CrossRef]

19. Elsallab, M.; Levine, B.; Wayne, A.; Abou-El-Enein, M. CAR T-cell product performance in haematological malignancies before and after marketing authorisation. Lancet. Oncol. 2020, 21, e104-e116. [CrossRef]

20. Hou, A.; Chen, L.; Chen, Y. Navigating CAR-T cells through the solid-tumour microenvironment. Nat. Rev. Drug Discov. 2021, 531-550. [CrossRef]

21. Brown, M.; Dustin, M. Steering CAR T Cells into Solid Tumors. N. Engl. J. Med. 2019, 380, 289-291. [CrossRef]

22. Köksal, H.; Müller, E.; Inderberg, E.; Bruland, Ø.; Wälchli, S. Treating osteosarcoma with CAR T cells. Scand. J. Immunol. 2019, 89, e12741. [CrossRef] [PubMed]

23. Park, J.; Cheung, N. GD2 or HER2 targeting T cell engaging bispecific antibodies to treat osteosarcoma. J. Hematol. Oncol. 2020, 13, 172. [CrossRef]

24. Huang, G.; Yu, L.; Cooper, L.J.; Hollomon, M.; Huls, H.; Kleinerman, E.S. Genetically modified T cells targeting interleukin-11 receptor $\alpha$-chain kill human osteosarcoma cells and induce the regression of established osteosarcoma lung metastases. Cancer Res. 2012, 72, 271-281. [CrossRef]

25. Huang, X.; Park, H.; Greene, J.; Pao, J.; Mulvey, E.; Zhou, S.; Albert, C.; Moy, F.; Sachdev, D.; Yee, D.; et al. IGF1R- and ROR1-Specific CAR T cells as a potential therapy for high risk sarcomas. PLoS ONE 2015, 10, e0133152. [CrossRef]

26. VanSeggelen, H.; Hammill, J.A.; Dvorkin-Gheva, A.; Tantalo, D.G.; Kwiecien, J.M.; Denisova, G.F.; Rabinovich, B.; Wan, Y.; Bramson, J.L. T cells engineered with chimeric antigen receptors targeting NKG2D ligands display lethal toxicity in mice. Mol. Ther. 2015, 23, 1600-1610. [CrossRef] [PubMed]

27. Wang, Y.; Yu, W.; Zhu, J.; Wang, J.; Xia, K.; Liang, C.; Tao, H. Anti-CD166/4-1BB chimeric antigen receptor T cell therapy for the treatment of osteosarcoma. J. Exp. Clin. Cancer Res. 2019, 38, 168. [CrossRef] 
28. Harrer, D.C.; Dörrie, J.; Schaft, N. CSPG4 as target for CAR-T-cell therapy of various tumor entities-merits and challenges. Int. J. Mol. Sci. 2019, 20, 5942. [CrossRef] [PubMed]

29. Majzner, R.G.; Theruvath, J.L.; Nellan, A.; Heitzeneder, S.; Cui, Y.; Mount, C.W.; Rietberg, S.P.; Linde, M.H.; Xu, P.; Rota, C.; et al. CAR T cells targeting B7-H3, a pan-cancer antigen, demonstrate potent preclinical activity against pediatric solid tumors and brain tumors. Clin. Cancer Res. 2019, 25, 2560-2574. [CrossRef] [PubMed]

30. Hsu, K.; Middlemiss, S.; Saletta, F.; Gottschalk, S.; McCowage, G.B.; Kramer, B. Chimeric antigen receptor-modified T cells targeting EphA2 for the immunotherapy of paediatric bone tumours. Cancer Gene Ther. 2021, 28, 321-334. [CrossRef] [PubMed]

31. Roskoski, R. The ErbB/HER family of protein-tyrosine kinases and cancer. Pharmacol. Res. 2014, 79, 34-74. [CrossRef] [PubMed]

32. Loibl, S.; Gianni, L. HER2-positive breast cancer. Lancet 2017, 389, 2415-2429. [CrossRef]

33. Baxevanis, C.; Sotiropoulou, P.; Sotiriadou, N.; Papamichail, M. Immunobiology of HER-2/neu oncoprotein and its potential application in cancer immunotherapy. Cancer Immunol. Immunother. 2004, 53, 166-175. [CrossRef]

34. Rainusso, N.; Brawley, V.; Ghazi, A.; Hicks, M.; Gottschalk, S.; Rosen, J.; Ahmed, N. Immunotherapy targeting HER2 with genetically modified T cells eliminates tumor-initiating cells in osteosarcoma. Cancer Gene Ther. 2012, 19, 212-217. [CrossRef]

35. Rashidijahanabad, Z.; Huang, X. Recent advances in tumor associated carbohydrate antigen based chimeric antigen receptor T cells and bispecific antibodies for anti-cancer immunotherapy. Semin. Immunol. 2020, 47, 101390. [CrossRef] [PubMed]

36. Lloyd, K.; Old, L. Human monoclonal antibodies to glycolipids and other carbohydrate antigens: Dissection of the humoral immune response in cancer patients. Cancer Res. 1989, 49, 3445-3451. [PubMed]

37. Long, A.; Highfill, S.; Cui, Y.; Smith, J.; Walker, A.; Ramakrishna, S.; El-Etriby, R.; Galli, S.; Tsokos, M.; Orentas, R.; et al. Reduction of MDSCs with all-trans retinoic acid improves CAR therapy efficacy for sarcomas. Cancer Immunol. Res. 2016, 4, 869-880. [CrossRef]

38. Chulanetra, M.; Morchang, A.; Sayour, E.; Eldjerou, L.; Milner, R.; Lagmay, J.; Cascio, M.; Stover, B.; Slayton, W.; Chaicumpa, W.; et al. GD2 chimeric antigen receptor modified T cells in synergy with sub-toxic level of doxorubicin targeting osteosarcomas. Am. J. Cancer Res. 2020, 10, 674-687.

39. Flem-Karlsen, K.; Fodstad, Ø.; Tan, M.; Nunes-Xavier, C.E. B7-H3 in Cancer-Beyond immune regulation. Trends Cancer 2018, 4, 401-404. [CrossRef] [PubMed]

40. Murty, S.; Labanieh, L.; Murty, T.; Gowrishankar, G.; Haywood, T.; Alam, I.S.; Beinat, C.; Robinson, E.; Aalipour, A.; Klysz, D.D.; et al. PET reporter gene imaging and ganciclovir-mediated ablation of chimeric antigen receptor T cells in solid tumors. Cancer Res. 2020, 80, 4731-4740. [CrossRef]

41. Yoshizaki, A.; Nakayama, T.; Yamazumi, K.; Yakata, Y.; Taba, M.; Sekine, I. Expression of interleukin (IL)-11 and IL-11 receptor in human colorectal adenocarcinoma: IL-11 up-regulation of the invasive and proliferative activity of human colorectal carcinoma cells. Int. J. Oncol. 2006, 29, 869-876. [CrossRef]

42. Pollak, M. The insulin and insulin-like growth factor receptor family in neoplasia: An update. Nat. Rev. Cancer 2012, 12, 159-169. [CrossRef]

43. Chitnis, M.M.; Yuen, J.S.; Protheroe, A.S.; Pollak, M.; Macaulay, V.M. The type 1 insulin-like growth factor receptor pathway. Clin. Cancer Res. 2008, 14, 6364-6370. [CrossRef] [PubMed]

44. Choi, M.; Widhopf, G.; Ghia, E.; Kidwell, R.; Hasan, M.; Yu, J.; Rassenti, L.; Chen, L.; Chen, Y.; Pittman, E.; et al. Phase I Trial: Cirmtuzumab Inhibits ROR1 Signaling and Stemness Signatures in Patients with Chronic Lymphocytic Leukemia. Cell Stem Cell 2018, 22, 951-959. [CrossRef]

45. Balakrishnan, A.; Goodpaster, T.; Randolph-Habecker, J.; Hoffstrom, B.; Jalikis, F.; Koch, L.; Berger, C.; Kosasih, P.; Rajan, A.; Sommermeyer, D.; et al. Analysis of ROR1 protein expression in human cancer and normal tissues. Clin. Cancer Res. 2017, 23, 3061-3071. [CrossRef] [PubMed]

46. Eagle, R.A.; Trowsdale, J. Promiscuity and the single receptor: NKG2D. Nat. Rev. Immunol. 2007, 7, 737-744. [CrossRef] [PubMed]

47. Fernández, L.; Metais, J.Y.; Escudero, A.; Vela, M.; Valentín, J.; Vallcorba, I.; Leivas, A.; Torres, J.; Valeri, A.; Patiño-García, A.; et al. Memory T cells expressing an NKG2D-CAR efficiently target osteosarcoma cells. Clin. Cancer Res. 2017, 23, 5824-5835. [CrossRef] [PubMed]

48. Flanagan, J.G.; Vanderhaeghen, P. The ephrins and Eph receptors in neural development. Annu. Rev. Neurosci. 1998, 21, 309-345. [CrossRef]

49. Lindberg, R.A.; Hunter, T. cDNA cloning and characterization of eck, an epithelial cell receptor protein-tyrosine kinase in the eph/elk family of protein kinases. Mol. Cell. Biol. 1990, 10, 6316-6324. [CrossRef]

50. Kang, B.H.; Jensen, K.J.; Hatch, J.A.; Janes, K.A. Simultaneous profiling of 194 distinct receptor transcripts in human cells. Sci. Signal. 2013, 6, rs13. [CrossRef]

51. Bowen, M.; Bajorath, J.; D’Egidio, M.; Whitney, G.; Palmer, D.; Kobarg, J.; Starling, G.; Siadak, A.; Aruffo, A. Characterization of mouse ALCAM (CD166): The CD6-binding domain is conserved in different homologs and mediates cross-species binding. Eur. J. Immunol. 1997, 27, 1469-1478. [CrossRef] [PubMed]

52. Ni, C.; Zhang, Z.; Zhu, X.; Liu, Y.; Qu, D.; Wu, P.; Huang, J.; Xu, A.X. Prognostic value of CD166 expression in cancers of the digestive system: A systematic review and meta-analysis. PLoS ONE 2013, 8, e70958. [CrossRef] [PubMed]

53. Riccardo, F.; Tarone, L.; Iussich, S.; Giacobino, D.; Arigoni, M.; Sammartano, F.; Morello, E.; Martano, M.; Gattino, F.; Maria, R.; et al. Identification of CSPG4 as a promising target for translational combinatorial approaches in osteosarcoma. Ther. Adv. Med. Oncol. 2019, 11, 1758835919855491. [CrossRef] 
54. Wang, X.; Wang, Y.; Yu, L.; Sakakura, K.; Visus, C.; Schwab, J.H.; Ferrone, C.R.; Favoino, E.; Koya, Y.; Campoli, M.R.; et al. CSPG4 in cancer: Multiple roles. Curr. Mol. Med. 2010, 10, 419-429. [CrossRef] [PubMed]

55. Nicolosi, P.A.; Dallatomasina, A.; Perris, R. Theranostic impact of NG2/CSPG4 proteoglycan in cancer. Theranostics 2015, 5, 530-544. [CrossRef] [PubMed]

56. Yarden, Y.; Sliwkowski, M. Untangling the ErbB signalling network. Nat. Rev. Mol. Cell Biol. 2001, 2, 127-137. [CrossRef]

57. Hughes, D.; Thomas, D.; Giordano, T.; Baker, L.; McDonagh, K. Cell surface expression of epidermal growth factor receptor and Her-2 with nuclear expression of Her-4 in primary osteosarcoma. Cancer Res. 2004, 64, 2047-2053. [CrossRef] [PubMed]

58. Hassan, S.; Bekarev, M.; Kim, M.; Lin, J.; Piperdi, S.; Gorlick, R.; Geller, D. Cell surface receptor expression patterns in osteosarcoma. Cancer 2012, 118, 740-749. [CrossRef]

59. Scotlandi, K.; Manara, M.; Hattinger, C.; Benini, S.; Perdichizzi, S.; Pasello, M.; Bacci, G.; Zanella, L.; Bertoni, F.; Picci, P.; et al. Prognostic and therapeutic relevance of HER2 expression in osteosarcoma and Ewing's sarcoma. Eur. J. Cancer 2005, 41, 1349-1361. [CrossRef]

60. Ahmed, N.; Brawley, V.; Hegde, M.; Robertson, C.; Ghazi, A.; Gerken, C.; Liu, E.; Dakhova, O.; Ashoori, A.; Corder, A.; et al. Human epidermal growth factor receptor 2 (HER2) -specific chimeric antigen receptor-modified T cells for the immunotherapy of HER2-positive sarcoma. J. Clin. Oncol. 2015, 33, 1688-1696. [CrossRef] [PubMed]

61. Morgan, R.; Yang, J.; Kitano, M.; Dudley, M.; Laurencot, C.; Rosenberg, S. Case report of a serious adverse event following the administration of T cells transduced with a chimeric antigen receptor recognizing ERBB2. Mol. Ther. 2010, 18, 843-851. [CrossRef]

62. Mata, M.; Vera, J.F.; Gerken, C.; Rooney, C.M.; Miller, T.; Pfent, C.; Wang, L.L.; Wilson-Robles, H.M.; Gottschalk, S. Toward immunotherapy with redirected $\mathrm{T}$ cells in a large animal model: Ex vivo activation, expansion, and genetic modification of canine T cells. J. Immunother. 2014, 37(8), 407-415. [CrossRef]

63. Suzuki, M.; Cheung, N. Disialoganglioside GD2 as a therapeutic target for human diseases. Expert Opin. Ther. Targets 2015, 19, 349-362. [CrossRef]

64. Yu, A.; Gilman, A.; Ozkaynak, M.; London, W.; Kreissman, S.; Chen, H.; Smith, M.; Anderson, B.; Villablanca, J.; Matthay, K.; et al. Anti-GD2 antibody with GM-CSF, interleukin-2, and isotretinoin for neuroblastoma. N. Engl. J. Med. 2010, 363, $1324-1334$. [CrossRef] [PubMed]

65. Roth, M.; Linkowski, M.; Tarim, J.; Piperdi, S.; Sowers, R.; Geller, D.; Gill, J.; Gorlick, R. Ganglioside GD2 as a therapeutic target for antibody-mediated therapy in patients with osteosarcoma. Cancer 2014, 120, 548-554. [CrossRef]

66. Parihar, R.; Rivas, C.; Huynh, M.; Omer, B.; Lapteva, N.; Metelitsa, L.S.; Gottschalk, S.M.; Rooney, C.M. NK cells expressing a chimeric activating receptor eliminate MDSCs and rescue impaired CAR-T cell activity against solid tumors. Cancer Immunol. Res. 2019, 7, 363-375. [CrossRef] [PubMed]

67. Steffin, D.; Heslop, H. Epigenetic inhibition puts target antigen in the crosshairs of CAR T cells. Mol. Ther. 2019, 27, 900-901. [CrossRef]

68. Liu, S.; Liang, J.; Liu, Z.; Zhang, C.; Wang, Y.; Watson, A.; Zhou, C.; Zhang, F.; Wu, K.; Zhang, F.; et al. The role of CD276 in cancers. Front. Oncol. 2021, 11, 654684. [CrossRef]

69. Kontos, F.; Michelakos, T.; Kurokawa, T.; Sadagopan, A.; Schwab, J.; Ferrone, C.; Ferrone, S. B7-H3: An attractive target for antibody-based immunotherapy. Clin. Cancer Res. 2021, 27, 1227-1235. [CrossRef]

70. Yang, S.; Wei, W.; Zhao, Q. B7-H3, a checkpoint molecule, as a target for cancer immunotherapy. Int. J. Biol. Sci. 2020, 16, 1767-1773. [CrossRef] [PubMed]

71. Zhou, X.; Ouyang, S.; Li, J.; Huang, X.; Ai, X.; Zeng, Y.; Lv, Y.; Cai, M. The novel non-immunological role and underlying mechanisms of B7-H3 in tumorigenesis. J. Cell. Physiol. 2019, 234, 21785-21795. [CrossRef]

72. Lichtman, E.; Du, H.; Shou, P.; Song, F.; Suzuki, K.; Ahn, S.; Li, G.; Ferrone, S.; Su, L.; Savoldo, B.; et al. Preclinical evaluation of B7-H3-specific chimeric antigen receptor T cells for the treatment of acute myeloid leukemia. Clin. Cancer Res. 2021, 3141-3153. [CrossRef]

73. Yonesaka, K.; Haratani, K.; Takamura, S.; Sakai, H.; Kato, R.; Takegawa, N.; Takahama, T.; Tanaka, K.; Hayashi, H.; Takeda, M.; et al. B7-H3 negatively modulates CTL-mediated cancer immunity. Clin. Cancer Res. 2018, 24, 2653-2664. [CrossRef] [PubMed]

74. Dondero, A.; Morini, M.; Cangelosi, D.; Mazzocco, K.; Serra, M.; Spaggiari, G.; Rotta, G.; Tondo, A.; Locatelli, F.; Castellano, A.; et al. Multiparametric flow cytometry highlights B7-H3 as a novel diagnostic/therapeutic target in GD2neg/low neuroblastoma variants. J. Immunother. Cancer 2021, 9, e002293. [CrossRef]

75. Onda, M.; Wang, Q.; Guo, H.; Cheung, N.; Pastan, I. In vitro and in vivo cytotoxic activities of recombinant immunotoxin 8H9(Fv)-PE38 against breast cancer, osteosarcoma, and neuroblastoma. Cancer Res. 2004, 64, 1419-1424. [CrossRef] [PubMed]

76. Theruvath, J.; Heitzeneder, S.; Majzner, R.; Moritz Graef, C.; Cui, K.; Nellan, A.; Cheshier, S.H.; Mackall, C.; Mitra, S. Immu-07. checkpoint molecule B7-H3 is highly expressed on medulloblastoma and proves to be a promising candidate for car T cell immunotherapy. Neuro. Oncol. 2017, 19, iv28-iv29. [CrossRef]

77. Chen, Y.; Tekle, C.; Fodstad, O. The immunoregulatory protein human B7H3 is a tumor-associated antigen that regulates tumor cell migration and invasion. Curr. Cancer Drug Targets 2008, 8, 404-413. [CrossRef]

78. Yin, S.; Wang, W.; Zhang, J. Expression of B7-H3 in cancer tissue during osteosarcoma progression in nude mice. Genet. Mol. Res. GMR 2015, 14, 14253-14261. [CrossRef]

79. Liu, H.; Tekle, C.; Chen, Y.W.; Kristian, A.; Zhao, Y.; Zhou, M.; Liu, Z.; Ding, Y.; Wang, B.; Mælandsmo, G.M.; et al. B7-H3 silencing increases paclitaxel sensitivity by abrogating Jak2/Stat3 phosphorylation. Mol. Cancer Ther. 2011, 10, 960-971. [CrossRef] 
80. Nunes-Xavier, C.E.; Karlsen, K.F.; Tekle, C.; Pedersen, C.; Øyjord, T.; Hongisto, V.; Nesland, J.M.; Tan, M.; Sahlberg, K.K.; Fodstad, $\varnothing$. Decreased expression of B7-H3 reduces the glycolytic capacity and sensitizes breast cancer cells to AKT/mTOR inhibitors. Oncotarget 2016, 7, 6891-6901. [CrossRef] [PubMed]

81. Campbell, C.L.; Jiang, Z.; Savarese, D.M.; Savarese, T.M. Increased expression of the interleukin-11 receptor and evidence of STAT3 activation in prostate carcinoma. Am. J. Pathol. 2001, 158, 25-32. [CrossRef]

82. Kishimoto, T.; Akira, S.; Narazaki, M.; Taga, T. Interleukin-6 family of cytokines and gp130. Blood 1995, 86, 1243. [CrossRef]

83. Kiessling, S.; Muller-Newen, G.; Leeb, S.N.; Hausmann, M.; Rath, H.C.; Strater, J.; Spottl, T.; Schlottmann, K.; Grossmann, J.; Montero-Julian, F.A. Functional Expression of the interleukin-11 receptor $\alpha$-chain and evidence of antiapoptotic effects in human colonic epithelial cells. J. Biol. Chem. 2004, 279, 10304-10315. [CrossRef] [PubMed]

84. Nakayama, T.; Yoshizaki, A.; Izumida, S.; Suehiro, T.; Miura, S.; Uemura, T.; Yakata, Y.; Shichijo, K.; Yamashita, S.; Sekin, I. Expression of interleukin-11 (IL-11) and IL-11 receptor alpha in human gastric carcinoma and IL-11 upregulates the invasive activity of human gastric carcinoma cells. Int. J. Oncol. 2007, 30, 825-833. [PubMed]

85. Lokau, J.; Schoeder, V.; Garbers, C. The role of interleukin-11 in osteosarcoma. Pathologe 2020, 41, 163-167. [CrossRef]

86. Lewis, V.O.; Ozawa, M.G.; Deavers, M.T.; Wang, G.; Shintani, T.; Arap, W.; Pasqualini, R. The interleukin-11 receptor alpha as a candidate ligand-directed target in osteosarcoma: Consistent data from cell lines, orthotopic models, and human tumor samples. Cancer Res. 2009, 69, 1995-1999. [CrossRef] [PubMed]

87. Liu, T.; Ma, Q.; Zhang, Y.; Ke, S.; Yan, K.; Chen, X.; Wen, Y.; Fan, Q.; Qiu, X. Interleukin-11 receptor $\alpha$ is overexpressed in human osteosarcoma, and near-infrared-labeled IL-11R $\alpha$ imaging agent could detect osteosarcoma in mouse tumor xenografts. Tumour Biol. 2015, 36, 2369-2375. [CrossRef]

88. Wang, Y.H.; Wang, Z.X.; Qiu, Y.; Xiong, J.; Chen, Y.X.; Miao, D.S.; De, W. Lentivirus-mediated RNAi knockdown of insulin-like growth factor-1 receptor inhibits growth, reduces invasion, and enhances radiosensitivity in human osteosarcoma cells. Mol. Cell. Biochem. 2009, 327, 257-266. [CrossRef]

89. Cao, Y.; Roth, M.; Piperdi, S.; Montoya, K.; Sowers, R.; Rao, P.; Geller, D.; Houghton, P.; Kolb, E.A.; Gill, J.; et al. Insulin-like growth factor 1 receptor and response to anti-IGF1R antibody therapy in osteosarcoma. PLoS ONE 2014, 9, e106249. [CrossRef]

90. Asmane, I.; Watkin, E.; Alberti, L.; Duc, A.; Marec-Berard, P.; Ray-Coquard, I.; Cassier, P.; Decouvelaere, A.V.; Ranchère, D.; Kurtz, J.E.; et al. Insulin-like growth factor type 1 receptor (IGF-1R) exclusive nuclear staining: A predictive biomarker for IGF-1R monoclonal antibody (Ab) therapy in sarcomas. Eur. J. Cancer 2012, 48, 3027-3035. [CrossRef]

91. Duan, Z.; Choy, E.; Harmon, D.; Yang, C.; Ryu, K.; Schwab, J.; Mankin, H.; Hornicek, F.J. Insulin-like growth factor-I receptor tyrosine kinase inhibitor cyclolignan picropodophyllin inhibits proliferation and induces apoptosis in multidrug resistant osteosarcoma cell lines. Mol. Cancer Ther. 2009, 8, 2122-2130. [CrossRef]

92. Dai, B.; Shen, Y.; Yan, T.; Zhang, A. Wnt5a/ROR1 activates DAAM1 and promotes the migration in osteosarcoma cells. Oncol. Rep. 2020, 43, 601-608. [CrossRef] [PubMed]

93. Srivastava, S.; Salter, A.I.; Liggitt, D.; Yechan-Gunja, S.; Sarvothama, M.; Cooper, K.; Smythe, K.S.; Dudakov, J.A.; Pierce, R.H.; Rader, C.; et al. Logic-gated ROR1 chimeric antigen receptor expression rescues $\mathrm{T}$ cell-mediated toxicity to normal tissues and enables selective tumor targeting. Cancer Cell 2019, 35, 489-503. [CrossRef] [PubMed]

94. Dhar, P.; Wu, J.D. NKG2D and its ligands in cancer. Curr. Opin. Immunol. 2018, 51, 55-61. [CrossRef]

95. Lazarova, M.; Steinle, A. The NKG2D axis: An emerging target in cancer immunotherapy. Expert Opin. Ther. Targets 2019, 23, 281-294. [CrossRef]

96. Frazao, A.; Rethacker, L.; Messaoudene, M.; Avril, M.F.; Toubert, A.; Dulphy, N.; Caignard, A. NKG2D/NKG2-ligand pathway offers new opportunities in cancer treatment. Front. Immunol. 2019, 10, 661. [CrossRef]

97. Lu, S.M.; Xiao, P.; Xue, L.; Che, L.H.; Yang, P.; Li, Y.; Qiao, H. Prevalent expression of MHC class I chain-related molecule A in human osteosarcoma. Neoplasma 2008, 55, 266-272.

98. Fernández, L.; Valentín, J.; Zalacain, M.; Leung, W.; Patiño-García, A.; Pérez-Martínez, A. Activated and expanded natural killer cells target osteosarcoma tumor initiating cells in an NKG2D-NKG2DL dependent manner. Cancer Lett. 2015, 368 , 54-63. [CrossRef]

99. Chang, Y.H.; Connolly, J.; Shimasaki, N.; Mimura, K.; Kono, K.; Campana, D. A chimeric receptor with NKG2D specificity enhances natural killer cell activation and killing of tumor cells. Cancer Res. 2013, 73, 1777-1786. [CrossRef] [PubMed]

100. Nikiforow, S.; Werner, L.; Murad, J.; Jacobs, M.; Johnston, L.; Patches, S.; White, R.; Daley, H.; Negre, H.; Reder, J.; et al. Safety data from a first-in-human phase 1 trial of NKG2D chimeric antigen receptor-T cells in AML/MDS and multiple myeloma. Blood 2016, 128, 4052. [CrossRef]

101. Pasquale, E.B. Eph receptors and ephrins in cancer: Bidirectional signalling and beyond. Nat. Rev. Cancer 2010, 10, 165-180. [CrossRef]

102. Wykosky, J.; Debinski, W. The EphA2 receptor and ephrinA1 ligand in solid tumors: Function and therapeutic targeting. Mol Cancer Res. 2008, 6, 1795-1806. [CrossRef] [PubMed]

103. Fritsche-Guenther, R.; Noske, A.; Ungethüm, U.; Kuban, R.J.; Schlag, P.M.; Tunn, P.U.; Karle, J.; Krenn, V.; Dietel, M.; Sers, C. De novo expression of EphA2 in osteosarcoma modulates activation of the mitogenic signalling pathway. Histopathology 2010, 57, 836-850. [CrossRef] 
104. Chiabotto, G.; Grignani, G.; Todorovic, M.; Martin, V.; Centomo, M.L.; Prola, E.; Giordano, G.; Merlini, A.; Miglio, U.; Berrino, E.; et al. Pazopanib and trametinib as a synergistic strategy against osteosarcoma: Preclinical activity and molecular insights. Cancers 2020, 12, 1519. [CrossRef]

105. Haghiralsadat, F.; Amoabediny, G.; Naderinezhad, S.; Zandieh-Doulabi, B.; Forouzanfar, T.; Helder, M.N. Codelivery of doxorubicin and JIP1 siRNA with novel EphA2-targeted PEGylated cationic nanoliposomes to overcome osteosarcoma multidrug resistance. Int. J. Nanomed. 2018, 13, 3853-3866. [CrossRef]

106. Haghiralsadat, F.; Amoabediny, G.; Naderinezhad, S.; Nazmi, K.; De Boer, J.P.; Zandieh-Doulabi, B.; Forouzanfar, T.; Helder, M.N. EphA2 targeted doxorubicin-nanoliposomes for osteosarcoma treatment. Pharm. Res. 2017, 34, 2891-2900. [CrossRef]

107. Posthumadeboer, J.; Piersma, S.R.; Pham, T.V.; van Egmond, P.W.; Knol, J.C.; Cleton-Jansen, A.M.; van Geer, M.A.; van Beusechem, V.W.; Kaspers, G.J.; van Royen, B.J.; et al. Surface proteomic analysis of osteosarcoma identifies EPHA2 as receptor for targeted drug delivery. Br. J. Cancer 2013, 109, 2142-2154. [CrossRef]

108. Xiao, M.; Wang, X.; Yan, M.; Chen, W. A systematic evaluation for the potential translation of CD166-related expression as a cancer biomarker. Expert Rev. Mol. Diagn. 2016, 16, 925-932. [CrossRef] [PubMed]

109. Hansen, A.G.; Arnold, S.A.; Jiang, M.; Palmer, T.D.; Ketova, T.; Merkel, A.; Pickup, M.; Samaras, S.; Shyr, Y.; Moses, H.L.; et al. ALCAM/CD166 is a TGF- $\beta$-responsive marker and functional regulator of prostate cancer metastasis to bone. Cancer Res. 2014, 74, 1404-1415. [CrossRef]

110. Levin, T.G.; Powell, A.E.; Davies, P.S.; Silk, A.D.; Dismuke, A.D.; Anderson, E.C.; Swain, J.R.; Wong, M.H. Characterization of the intestinal cancer stem cell marker CD166 in the human and mouse gastrointestinal tract. Gastroenterology 2010, 139, $2072-2082$. [CrossRef] [PubMed]

111. Kijima, N.; Hosen, N.; Kagawa, N.; Hashimoto, N.; Nakano, A.; Fujimoto, Y.; Kinoshita, M.; Sugiyama, H.; Yoshimine, T. CD166/activated leukocyte cell adhesion molecule is expressed on glioblastoma progenitor cells and involved in the regulation of tumor cell invasion. Neuro Oncol. 2012, 14, 1254-1264. [CrossRef] [PubMed]

112. Stanley, K.T.; VanDort, C.; Motyl, C.; Endres, J.; Fox, D.A. Immunocompetent properties of human osteoblasts: Interactions with T lymphocytes. J. Bone Min. Res. 2006, 21, 29-36. [CrossRef] [PubMed]

113. Wang, T.; Wang, D.; Zhang, L.; Yang, P.; Wang, J.; Liu, Q.; Yan, F.; Lin, F. The TGFß-miR-499a-SHKBP1 pathway induces resistance to EGFR inhibitors in osteosarcoma cancer stem cell-like cells. J. Exp. Clin. Cancer Res. 2019, 38, 226. [CrossRef]

114. Federman, N.; Chan, J.; Nagy, J.O.; Landaw, E.M.; McCabe, K.; Wu, A.M.; Triche, T.; Kang, H.; Liu, B.; Marks, J.D.; et al. Enhanced growth inhibition of osteosarcoma by cytotoxic polymerized liposomal nanoparticles targeting the alcam cell surface receptor. Sarcoma 2012, 2012, 126906. [CrossRef] [PubMed]

115. Ikeda, K.; Quertermous, T. Molecular isolation and characterization of a soluble isoform of activated leukocyte cell adhesion molecule that modulates endothelial cell function. J. Biol. Chem. 2004, 279, 55315-55323. [CrossRef]

116. Saifullah, M.K.; Fox, D.A.; Sarkar, S.; Abidi, S.M.; Endres, J.; Piktel, J.; Haqqi, T.M.; Singer, N.G. Expression and characterization of a novel CD6 ligand in cells derived from joint and epithelial tissues. J. Immunol. 2004, 173, 6125-6133. [CrossRef]

117. Thelen, K.; Jaehrling, S.; Spatz, J.P.; Pollerberg, G.E. Depending on its nano-spacing, ALCAM promotes cell attachment and axon growth. PLOS ONE 2012, 7, e40493. [CrossRef]

118. Tarone, L.; Barutello, G.; Iussich, S.; Giacobino, D.; Quaglino, E.; Buracco, P.; Cavallo, F.; Riccardo, F. Naturally occurring cancers in pet dogs as pre-clinical models for cancer immunotherapy. Cancer Immunol. Immunother. 2019, 68, 1839-1853. [CrossRef]

119. Mirabello, L.; Troisi, R.J.; Savage, S.A. International osteosarcoma incidence patterns in children and adolescents, middle ages and elderly persons. Int. J. Cancer 2009, 125, 229-234. [CrossRef]

120. Misaghi, A.; Goldin, A.; Awad, M.; Kulidjian, A.A. Osteosarcoma: A comprehensive review. SICOT J. 2018, 4, 12. [CrossRef] [PubMed]

121. Goorin, A.M.; Harris, M.B.; Bernstein, M.; Ferguson, W.; Devidas, M.; Siegal, G.P.; Gebhardt, M.C.; Schwartz, C.L.; Link, M.; Grier, H.E. Phase II/III trial of etoposide and high-dose ifosfamide in newly diagnosed metastatic osteosarcoma: A pediatric oncology group trial. J. Clin. Oncol. 2002, 20, 426-433. [CrossRef] [PubMed]

122. Jafari, F.; Javdansirat, S.; Sanaie, S.; Naseri, A.; Shamekh, A.; Rostamzadeh, D.; Dolati, S. Osteosarcoma: A comprehensive review of management and treatment strategies. Ann. Diagn. Pathol. 2020, 49, 151654. [CrossRef] [PubMed]

123. PosthumaDeBoer, J.; Witlox, M.A.; Kaspers, G.J.; van Royen, B.J. Molecular alterations as target for therapy in metastatic osteosarcoma: A review of literature. Clin. Exp. Metastasis 2011, 28, 493-503. [CrossRef] [PubMed]

124. Hinrichs, C.S.; Borman, Z.A.; Cassard, L.; Gattinoni, L.; Spolski, R.; Yu, Z.; Sanchez-Perez, L.; Muranski, P.; Kern, S.J.; Logun, C.; et al. Adoptively transferred effector cells derived from naive rather than central memory CD8+ T cells mediate superior antitumor immunity. Proc. Natl. Acad. Sci. USA 2009, 106, 17469-17474. [CrossRef] [PubMed]

125. Hong, M.S.; Dan, J.M.; Choi, J.Y.; Kang, I. Age-associated changes in the frequency of naïve, memory and effector CD8+ T cells. Mech. Ageing Dev. 2004, 125, 615-618. [CrossRef]

126. Shah, N.; Fry, T. Mechanisms of resistance to CAR T cell therapy. Nat. Rev. Clin. Oncol. 2019, 16, 372-385. [CrossRef] [PubMed]

127. Majzner, R.G.; Mackall, C.L. Tumor antigen escape from CAR T-cell therapy. Cancer Discov. 2018, 8, 1219-1226. [CrossRef] [PubMed]

128. Klebanoff, C.; Rosenberg, S.; Restifo, N. Prospects for gene-engineered T cell immunotherapy for solid cancers. Nat. Med. 2016, 22, 26-36. [CrossRef] 
129. Liu, X.; Jiang, S.; Fang, C.; Yang, S.; Olalere, D.; Pequignot, E.C.; Cogdill, A.P.; Li, N.; Ramones, M.; Granda, B.; et al. Affinity-tuned ErbB2 or EGFR chimeric antigen receptor T cells exhibit an increased therapeutic index against tumors in mice. Cancer Res. 2015, 75, 3596-3607. [CrossRef]

130. Caruso, H.G.; Hurton, L.V.; Najjar, A.; Rushworth, D.; Ang, S.; Olivares, S.; Mi, T.; Switzer, K.; Singh, H.; Huls, H.; et al. Tuning sensitivity of CAR to EGFR density limits recognition of normal tissue while maintaining potent antitumor activity. Cancer Res. 2015, 75, 3505-3518. [CrossRef] [PubMed]

131. Bielamowicz, K.; Fousek, K.; Byrd, T.T.; Samaha, H.; Mukherjee, M.; Aware, N.; Wu, M.F.; Orange, J.S.; Sumazin, P.; Man, T.K.; et al. Trivalent CAR T cells overcome interpatient antigenic variability in glioblastoma. Neuro Oncol. 2018, 20, 506-518. [CrossRef]

132. Finney, H.M.; Akbar, A.N.; Lawson, A.D. Activation of resting human primary T cells with chimeric receptors: Costimulation from CD28, inducible costimulator, CD134, and CD137 in series with signals from the TCR zeta chain. J. Immunol. 2004, 172, 104-113. [CrossRef] [PubMed]

133. Craddock, J.A.; Lu, A.; Bear, A.; Pule, M.; Brenner, M.K.; Rooney, C.M.; Foster, A.E. Enhanced tumor trafficking of GD2 chimeric antigen receptor $\mathrm{T}$ cells by expression of the chemokine receptor CCR2b. J. Immunother. 2010, 33, 780-788. [CrossRef] [PubMed]

134. Moon, E.K.; Carpenito, C.; Sun, J.; Wang, L.C.; Kapoor, V.; Predina, J.; Powell, D.J., Jr.; Riley, J.L.; June, C.H.; Albelda, S.M. Expression of a functional CCR2 receptor enhances tumor localization and tumor eradication by retargeted human $\mathrm{T}$ cells expressing a mesothelin-specific chimeric antibody receptor. Clin. Cancer Res. 2011, 17, 4719-4730. [CrossRef]

135. Caruana, I.; Savoldo, B.; Hoyos, V.; Weber, G.; Liu, H.; Kim, E.S.; Ittmann, M.M.; Marchetti, D.; Dotti, G. Heparanase promotes tumor infiltration and antitumor activity of CAR-redirected T lymphocytes. Nat. Med. 2015, 21, 524-529. [CrossRef] [PubMed]

136. Sukumaran, S.; Watanabe, N.; Bajgain, P.; Raja, K.; Mohammed, S.; Fisher, W.E.; Brenner, M.K.; Leen, A.M.; Vera, J.F. Enhancing the potency and specificity of engineered T cells for cancer treatment. Cancer Discov. 2018, 8, 972-987. [CrossRef]

137. Feucht, J.; Sun, J.; Eyquem, J.; Ho, Y.J.; Zhao, Z.; Leibold, J.; Dobrin, A.; Cabriolu, A.; Hamieh, M.; Sadelain, M. Calibration of CAR activation potential directs alternative $\mathrm{T}$ cell fates and therapeutic potency. Nat. Med. 2019, 25, 82-88. [CrossRef]

138. Fedorov, V.D.; Themeli, M.; Sadelain, M. PD-1- and CTLA-4-based inhibitory chimeric antigen receptors (iCARs) divert off-target immunotherapy responses. Sci. Transl. Med. 2013, 5, 215ra172. [CrossRef]

139. Bernheim, A. Cytogenomics of cancers: From chromosome to sequence. Mol. Oncol. 2010, 4, 309-322. [CrossRef]

140. Zwerner, J.; Joo, J.; Warner, K.; Christensen, L.; Hu-Lieskovan, S.; Triche, T.; May, W. The EWS/FLI1 oncogenic transcription factor deregulates GLI1. Oncogene 2008, 27, 3282-3291. [CrossRef] [PubMed]

141. Tirado, O.; Mateo-Lozano, S.; Villar, J.; Dettin, L.; Llort, A.; Gallego, S.; Ban, J.; Kovar, H.; Notario, V. Caveolin-1 (CAV1) is a target of EWS/FLI-1 and a key determinant of the oncogenic phenotype and tumorigenicity of Ewing's sarcoma cells. Cancer Res. 2006, 66, 9937-9947. [CrossRef]

142. Grünewald, T.; Bernard, V.; Gilardi-Hebenstreit, P.; Raynal, V.; Surdez, D.; Aynaud, M.; Mirabeau, O.; Cidre-Aranaz, F.; Tirode, F.; Zaidi, S.; et al. Chimeric EWSR1-FLI1 regulates the Ewing sarcoma susceptibility gene EGR2 via a GGAA microsatellite. Nat. Genet. 2015, 47, 1073-1078. [CrossRef] [PubMed]

143. Rathe, S.; Popescu, F.; Johnson, J.; Watson, A.; Marko, T.; Moriarity, B.; Ohlfest, J.; Largaespada, D. Identification of candidate neoantigens produced by fusion transcripts in human osteosarcomas. Sci. Rep. 2019, 9, 358. [CrossRef] [PubMed]

144. Liang, X.; Wang, X.; He, Y.; Wu, Y.; Zhong, L.; Liu, W.; Liao, D.; Kang, T. Acetylation dependent functions of Rab22a-NeoF1 fusion protein in osteosarcoma. Theranostics 2020, 10, 7747-7757. [CrossRef]

145. Liao, D.; Zhong, L.; Yin, J.; Zeng, C.; Wang, X.; Huang, X.; Chen, J.; Zhang, H.; Zhang, R.; Guan, X.; et al. Chromosomal translocation-derived aberrant Rab22a drives metastasis of osteosarcoma. Nat. Cell Biol. 2020, 22, 868-881. [CrossRef]

146. Xie, K.; Zhang, X.; Tao, Y. Rab22a-NeoF1: A promising target for osteosarcoma patients with lung metastasis. Signal. Transduct. Target. Ther. 2020, 5, 161. [CrossRef] [PubMed]

147. Zhong, L.; Liao, D.; Li, J.; Liu, W.; Wang, J.; Zeng, C.; Wang, X.; Cao, Z.; Zhang, R.; Li, M.; et al. Rab22a-NeoF1 fusion protein promotes osteosarcoma lung metastasis through its secretion into exosomes. Signal. Transduct. Target. Ther. 2021, 6, 59. [CrossRef] [PubMed]

148. Debelenko, L.V.; McGregor, L.M.; Shivakumar, B.R.; Dorfman, H.D.; Raimondi, S.C. A novel EWSR1-CREB3L1 fusion transcript in a case of small cell osteosarcoma. Genes Chromosomes Cancer 2011, 50, 1054-1062. [CrossRef] [PubMed]

149. Saba, K.; Cornmark, L.; Rissler, M.; Fioretos, T.; Åström, K.; Haglund, F.; Rosenberg, A.; Brosjö, O.; Nord, K. Genetic profiling of a chondroblastoma-like osteosarcoma/malignant phosphaturic mesenchymal tumor of bone reveals a homozygous deletion of CDKN2A, intragenic deletion of DMD, and a targetable FN1-FGFR1 gene fusion. Genes Chromosomes Cancer 2019, 58, 731-736. [CrossRef] 